\title{
TEXTILE WASTEWATER REUSE AFTER PHOTO- FENTON TREATMENT USING FE(II) AND FERRIOXALATE
}

\author{
M. C. STARLING ${ }^{1 *}$, L. A. S. CASTRO ${ }^{1}$, R. B. P. MARCELINO ${ }^{1}$, C. C. AMORIM ${ }^{1}$, \\ M. M. D. LEÃO ${ }^{1}$ \\ ${ }^{1}$ Universidade Federal de Minas Gerais, Departamento de Engenharia Sanitária e \\ Ambiental \\ *E-mail para contato: cacastarling@ hotmail.com
}

\begin{abstract}
The textile industry is responsible for generating a large amount of a very complex wastewater during its production process. This wastewater contains residual dyes, high concentration of salt, soaps and detergents. Also, dyes used in the process are soluble in water, but not biodegradable and may be toxic for the environment. The present work proposes using advanced chemical oxidation (AOP) applying the photoFenton process in order to evaluate the feasibility of water reuse in the textile industry production process. Reactions were conducted in a bench photo-reactor with radiation, both UV and UV-vis and testing Iron Sulfate and Ferrioxalate as Iron (II) sources. Also, an experimental design was followed in which initial concentrations of $\mathrm{Fe}$ (II) and $\mathrm{H}_{2} \mathrm{O}_{2}$ varied from 4-20 $\mathrm{mg} / \mathrm{L}$ and $100-500 \mathrm{mg} / \mathrm{l}$, respectively. Response variables monitored were TOC $(\mathrm{mg} / \mathrm{L})$ and residual $\mathrm{H}_{2} \mathrm{O}_{2}(\mathrm{mg} / \mathrm{L})$. For a $\mathrm{pH}$ equals 3 in a molar rate of $\mathrm{Fe} / \mathrm{H}_{2} \mathrm{O}_{2} \approx 0,4: 3$, TOC reduction obtained was $98,4 \%$ and residual concentration of $\mathrm{H}_{2} \mathrm{O}_{2}$ was $2,6 \mathrm{mg} / \mathrm{l}$. Results favor textile wastewater reuse after AOP treatment.
\end{abstract}

\section{INTRODUCTION}

A great amount of water is used by the textile industries during its production process (MEIHONG et al., 2011). Since different chemicals are applied at each stage of production the wastewater generated is complex and contains a great range of organic, inorganic, hydro and oleofilic components. After the dye-ing stage, for example, around fifty per cent of the dyes may end up in the wastewater streams (KHANDEGAR e SAROHA, 2013). Dyes consist of complex structures which are hard to degrade and do not fade when exposed to light, thus, affecting wastewater color (CHUAH et al., 2005).

Since there is a large diversity of dyes available in the market, the resultant wastewater varies in composition (CARNEIRO et al., 2006). Wastewater variability may occur not only between distinct producers, but also for the same industry in different cycles of production. Moreover, dyes can be toxic for the environment and disable some usual treatments available for wastewater treatment such as biological treatment (GOMATHI DEVI et al., 2009). Therefore, textile industry wastewater treatment is complex and should be looked into for the establishment of a more efficient method in order to enable water reuse. 
Currently, the most usual treatment used for textile wastewater is chemicalphysical treatment (AHMAD and HAMEED, 2010). Various chemical processes such as precipitation, oxidation and adsorption have been tested for their efficiency and effects upon consecutive biological treatment. The oxidation treatment has been proved to be very effective, depending on the oxidant used (VILAR et al., 2011). Regarding water reuse in the textile industry there is no specific Brazilian legislation on the theme. However, it is mainly important to achieve, reduction of color, organic matter and a neutral $\mathrm{pH}$ in order to avoid production problems (DWAF, 1996; RESENDE, 2012; USEPA, 2004).

For the past twenty years, advanced oxidation processes (AOPs) have been used for treatment of recalcitrant pollutants in solution, such as dyes. AOPs aim for pollutants' mineralization not only a mere change of phase (CARNEIRO et al., 2006). These methods involve production of $\mathrm{OH}$ radicals $\left({ }^{\circ} \mathrm{OH}\right)$ which react with pollutants, thus, degrading them. One of the process' advantages is that different species can be used for radical generation allowing alternatives that will be more suitable for each system.

One of the processes used as an advanced oxidation process is Fenton, which has been used in laboratory and industrial conditions for the treatment of different wastewaters. This system has been described to be the most adequate for discoloration with great energy efficiency (GOGATE and PANDIT, 2004). In this process ( $\left.{ }^{\circ} \mathrm{OH}\right)$ radical is formed when hydrogen peroxide $\left(\mathrm{H}_{2} \mathrm{O}_{2}\right)$ is in the presence of a ferrous salt. Different sources of ferrous ions can be used, such as Iron Sulfate $\left(\mathrm{FeSO}_{4}\right)$ and ferrioxalate (Fe(III)-polycarboxylate). It is important to note that exposure to light (UV/UV-vis/Solar) may enhance the production of reactive radicals. Therefore, photoFenton systems have been widely studied recently (WILL et al., 2004). Some innovative works have been testing the use of solar radiation as the source of light for photo-Fenton. Solar-photo reactors may decrease costs, being beneficial for industrial scale processes (MONTEAGUDO et al., 2011).

Hydroxyl radical $\left({ }^{\circ} \mathrm{OH}\right)$ is able to reduce the majority of the organic molecules due to its extremely high redox potential $\left(\mathrm{E}^{0}=2,8 \mathrm{~V}\right)$. For this reason, it is not considered highly selective which suits the textile industry production requisites once its wastewater has a wide range of chemicals. In order to achieve higher efficiency, it is important to monitor temperature, $\mathrm{pH}, \mathrm{H}_{2} \mathrm{O}_{2}$ concentration and molar rate between $\mathrm{Fe}$ (II) and $\mathrm{H}_{2} \mathrm{O}_{2}$ during the Fenton process. Optimum temperature ranges from $20-40^{\circ} \mathrm{C}$. Depending on the wastewater $\mathrm{pH}$ and iron source, pre-adjustment of system's to lower $\mathrm{pH}$ is required once high $\mathrm{pH}$ will affect course of reactions and may cause Iron(II) precipitation (WANG et al., 2008). Iron may be added to the system either as Iron Sulfate $\left(\mathrm{FeSO}_{4}\right)$ or ferrioxalate $\left(\left[\mathrm{Fe}\left(\mathrm{C}_{2} \mathrm{O}_{4}\right)_{3}\right]^{3-}\right)$. It is known that when ferrioxalate is used, Iron(II) stability compromises a broader pH range (DIAS et al., 2014). Also, it has higher light spectrum absorbance and decreases absorption of light by other chemical compounds, increasing photo-Fenton efficiency. Regarding $\mathrm{H}_{2} \mathrm{O}_{2}$, its excess may disrupt the system since it consumes ${ }^{\circ} \mathrm{OH}$ with production of $\mathrm{HO}_{2}{ }^{\circ}$ (AMORIM et al., 2009).

The present work aims to evaluate the potential of water re-use in the textile industry after treatment with photo-Fenton (UV and Vis) in a laboratory scale experiment. In order to optimize results, reactions were conducted under different 
conditions of $\mathrm{pH}$, mass of Iron(II) from $\mathrm{FeSO}_{4}$ or ferrioxalate and $\mathrm{H}_{2} \mathrm{O}_{2}$ concentrations. Response-variables evaluated during the experiment were dissolved organic carbon (TOC) and residual $\mathrm{H}_{2} \mathrm{O}_{2}$.

\section{MATERIALS AND METHODS \\ 3.1. Textile Industry Wastewater}

The samples of wastewater used in this work were collected from a textile industry located in Minas Gerais. It produces 400 tons of tissue/month and consumes 48,3 thousand $\mathrm{m}^{3}$ of water/month. In this industry, pure water is collected from a well and is used for the production process of light colored tissue and other processes such as cleaning, cooking, irrigation, boiler and restrooms. After used for light colored tissue production the water contains low concentration of chemical products and soaps. Then, it is collected and treated in a first recovery pond, goes through a membrane filter for solids detainment and flows to a second pond. From there, water returns to the process for production of darker colored tissues. Dark colored tissue production water has high chemical content. Thus, it flows straight to the industrial water treatment plant (IWTP) which applies the activated sludge biological treatment. After this former step, water can be disposed in the stream again (Figure 1). There is no sanitary swage mix with industrial wastewater in the process.

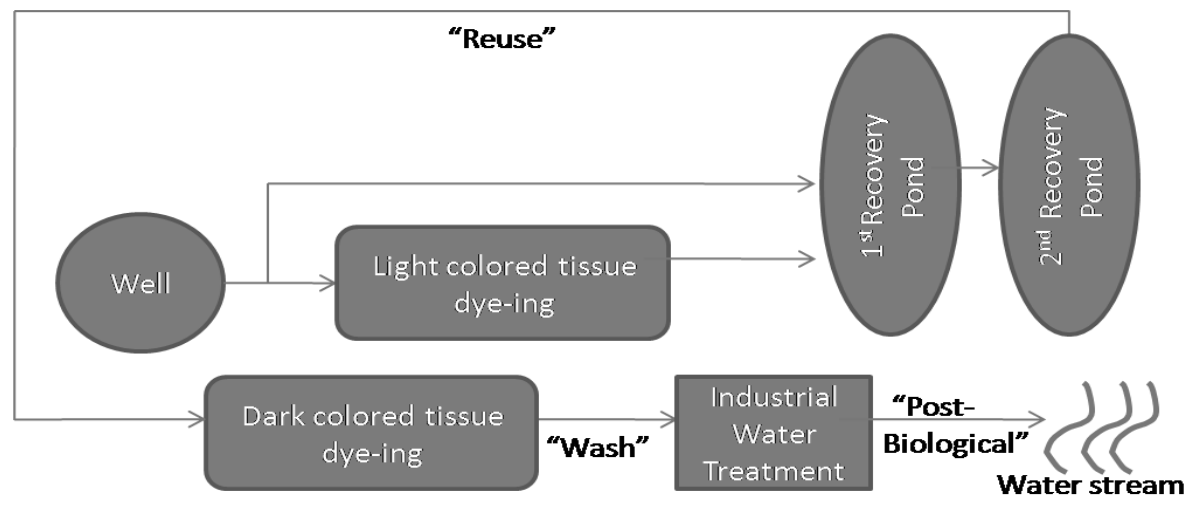

Figure 1- Textile Industry Production Flow Chart.

For better understanding this work, the three types of wastewater tested were named differently, according to the step from which they were generated. The "Reuse" $(\mathrm{R})$, is that one from light colored tissue production. "Wash" (W) and "Post-Biological" (PB) represent, respectively, wastewater from dark colored tissue production and the one that is disposed in the water body after biological treatment (Figure 1).

\subsection{Wastewater Previous Characterization and Photo-Fenton Reaction}

Before photo-Fenton reaction, each sample was characterized for its total Chemical Oxygen Demand (COD, $\mathrm{mg} \mathrm{O}_{2} / \mathrm{L}$ ) through the Colorimetric method (APHA 5220 D), color (Platinum-Cobalt Standard Method 8025) and $\mathrm{pH}$ (potentiometric method). Total Carbon (TC; mg/L) and Total Dissolved Carbon (TDC; mg/L) were quatified by a Total Organic Carbon Analyzer (Shimadzu). 
Photo-Fenton experiments were conducted in a laboratory scale photo reactor. This reactor has an interior glass container with total volume of $0,9 \mathrm{~L}$ (10 cm diameter; height of $15 \mathrm{~cm}$ ) which is involved by a PVC tube in order to keep constant temperature during the experiment. For the experiments conducted using UV light, a mercury lamp, $80 \mathrm{~W}$ power light bulb covered by quartz was used. Whereas, for those using Vis light the mercury lamp, $80 \mathrm{~W}$ power bulb was that covered by borosilicate glass. Both of them were placed separately inside each reactor's glass container during the experiments.

For each wastewater sample, 10 different conditions were tested. Initial $\mathrm{pH}$ was pre adjusted to either 3, when using Iron Sulfate as Iron(II) source (samples 1-5), or $\mathrm{pH}=5$ for ferrioxalate as the Iron(III) source (samples 1'-5'). It is important to highlight that for both iron sources, solid $\mathrm{FeSO}_{4} .7 \mathrm{H}_{2} \mathrm{O}$ is weighed. However, for the experiments with $\mathrm{Fe}(\mathrm{III})$, oxalate acid is added at a concentration of $80 \mathrm{mg} / \mathrm{L}$ to the reaction so that ferrioxalate complexes may be formed. Iron and $\mathrm{H}_{2} \mathrm{O}_{2}$ were added in concentrations of the 4-20 mg/L of iron (II) and 100-500 mg/L of $\mathrm{H}_{2} \mathrm{O}_{2}$. Concentrations used were chosen based wastewaters' organic matter content and literature review. Also, Fe recovery has not been studied in the experiments conducted here, since concentrations used are already relatively low.

Samples of each one of these experiments, from 1 to $5\left(\mathrm{FeSO}_{4}\right)$ and 1'-5' $\left(\left[\mathrm{Fe}\left(\mathrm{C}_{2} \mathrm{O}_{4}\right)_{3}\right]^{3-}\right)$ were collected at times (min): 0', 5', 10', 15', 30', 45', 60', 90' and 120' in order to evaluate TDC, $\mathrm{H}_{2} \mathrm{O}_{2}$ residual concentration using the spectrophotometer metavanadate method as described by Nogueira (2005) and color (nm). Bench reactors used are attached to a cooling system, temperature was kept at $25 \mathrm{C}$ during the entire time for all of the samples. Right after collection of each sample, reaction was stopped with the addition of catalase in order to disable peroxide influence on TDC results as described by Amorim et al., 2012.

\section{RESULTS AND DISCUSSION}

Wastewater characterization, Table 1 , shows results for the three types of wastewater collected.

Table 1 - Physical-Chemical Characterization of Wastewater Results

\begin{tabular}{cccc}
\hline Parameter & Reuse & Wash & Post-Bio \\
\hline $\mathrm{COD}\left(\mathrm{mg} \mathrm{O}_{2} / \mathrm{L}\right)$ & 27 & 242 & 147 \\
$\mathrm{pH}$ & 7,17 & 8,2 & 7,2 \\
Color $(\mathrm{mgPt} / \mathrm{L})$ & 144 & 915 & 523 \\
$\mathrm{TC}(\mathrm{mg} / \mathrm{L})$ & 30,1 & 60,5 & 68,7 \\
$\mathrm{TOC}(\mathrm{mg} / \mathrm{L})$ & 7,1 & 41,2 & 31,6 \\
\hline
\end{tabular}

As expected, color in "wash" wastewater was proved to be the highest one, since it comes from dark colored tissue production process. Also, COD and TOC are greater in this wastewater when compared to "reuse" and "post-bio" ones which also must be due to higher amount of organic chemical molecules such as dyes (KHANDEGAR e SAROHA, 2013).

As far as results from the photo-Fenton reaction with "wash" wastewater, since it was the one with highest initial values of organic matter and color, the experiment that obtained best results was that with $20 \mathrm{mg} / \mathrm{L}$ of $\mathrm{Fe}(\mathrm{II})$ and $100 \mathrm{mg} / \mathrm{L} \mathrm{of} \mathrm{H}_{2} \mathrm{O}_{2}$, using 
UV light (Figures 2A and 2B). This condition reduced TDC to half of initial value within the first five minutes of reaction (Figure 2B). Best result is achieved when the biggest concentration of $\mathrm{Fe}$ (II) is added to system, while the optimum concentration for $\mathrm{H}_{2} \mathrm{O}_{2}$ is the lowest one. This indicates that when in concentrations higher than 100 $\mathrm{mg} / \mathrm{L}$, hydrogen peroxide may be in excess (AMORIM et al., 2009). Also, there is only a $3,5 \%$ difference when using 4 or $20 \mathrm{mg} / \mathrm{L}$ of $\mathrm{Fe}(\mathrm{II})$. Since both achieved a degradation rate higher than $90 \%$, it must be more economic to work with lower $\mathrm{Fe}$ (II) concentrations. However, for their kinetics, when comparing the use of 4 or $20 \mathrm{mg} / \mathrm{L}$ $\mathrm{Fe}(\mathrm{II})$, both with $\mathrm{H}_{2} \mathrm{O}_{2}$ at $100 \mathrm{mg} / \mathrm{L}$, Figure 2 shows a slower reaction rate when using 4 $\mathrm{mg} / \mathrm{L}$ of $\mathrm{Fe}(\mathrm{II})$.

$2 \mathrm{~A}$

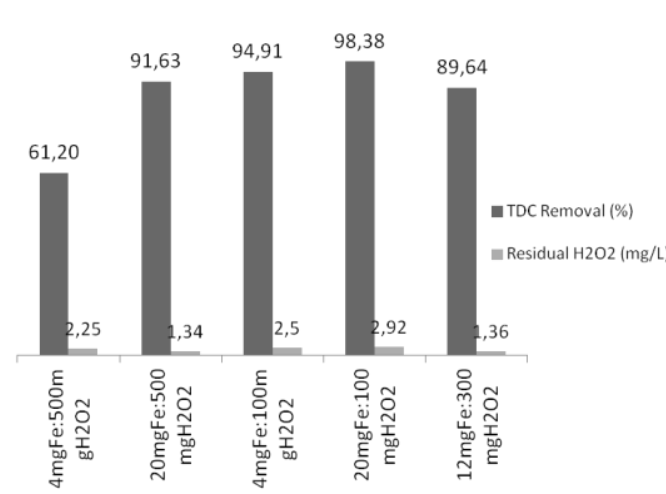

2B

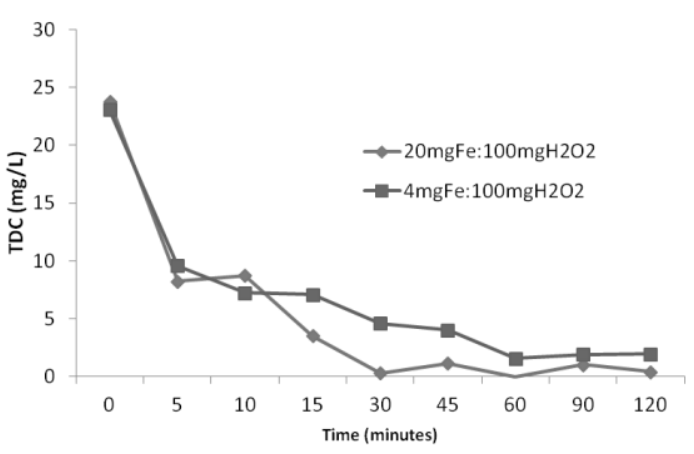

Figure 2: (2A) Percentage removal of TDC and residual peroxide for "Wash" wastewater using $\mathrm{UV}$ and $\mathrm{FeSO}_{4}$. (2B) Kinetics of TDC removal during the UV-Fenton Process using 4 and 20 $\mathrm{mg} / \mathrm{L}$ of $\mathrm{Fe}(\mathrm{II})$ and $100 \mathrm{mg} / \mathrm{L}$ of $\mathrm{H}_{2} \mathrm{O}_{2}$ and Iron Sulfate as Iron(II) source.

Results obtained with the "reuse" and "post-bio" wastewaters also showed great method efficiency on TDC removal. Maximum reduction of TDC $(\mathrm{mg} / \mathrm{L})$ for PB was equal $88.6 \%$ with a minimum residual $\mathrm{H}_{2} \mathrm{O}_{2}$ of $1.06 \mathrm{mg} / \mathrm{L}$. However, for $\mathrm{PB}$ wastewater, best results were achieved with the maximum mass of both $\mathrm{H}_{2} \mathrm{O}_{2}(500$ $\mathrm{mg} / \mathrm{L})$ and $\mathrm{Fe}(\mathrm{II})(20 \mathrm{mg} / \mathrm{L})$. Despite showing lower COD than the wash wastewater, PB probably is made of more recalcitrant components once it has already been through a previous treatment. Therefore, it requires higher concentration of reagents in order to be degraded by the Fenton process.

Regarding "reuse" wastewater, since it is the one with the initial lowest content of organic matter, all of the conditions obtained $100 \%$ TDC reduction, while residual $\mathrm{H}_{2} \mathrm{O}_{2}$ varied from $0,8-2,74 \mathrm{mg} / \mathrm{L}$. These results were obtained within 5 minutes of reaction and reinforce the fact that reuse wastewater can be used for another the production cycle process without negative impacts on final product quality.

When compared to pure wastewater (Figure 3A), color was greatly and visually (Figure 3B) reduced for all of the concentrations of $\mathrm{Fe}(\mathrm{II})$ and $\mathrm{H}_{2} \mathrm{O}_{2}$ used after photoFenton treatment for all of the wastewater types.

Both organic matter and color are main concerns when aiming water reuse in the textile industry and results obtained here meet the requirements (RESENDE, 2012). Therefore, photo-Fenton treatment may enable water reuse in the textile industry which leads to water conservation. 
$3 A$

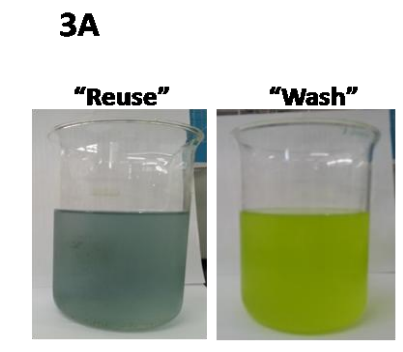

3B

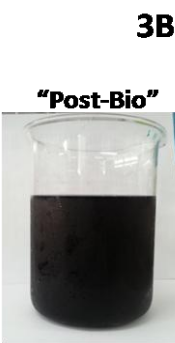

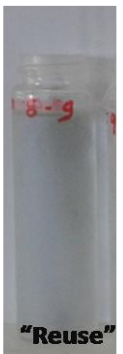
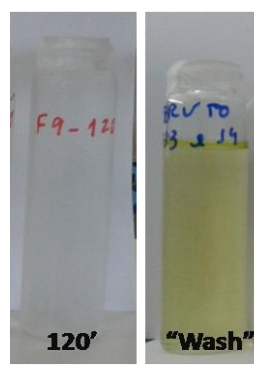

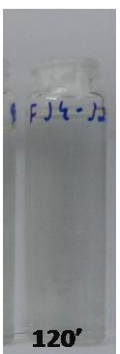

Figure 3: (3A) Reuse, Wash and Post-Bio wastewaters before treatment. (3B) Reuse and Wash wastewater and their samples after 120' of photo-Fenton reaction.

However, some limitations should be taken into account: $\mathrm{pH}$ adjustment must be done before and after photo-Fenton treatment and, as a result, an undesired sludge may be formed due to $\mathrm{Fe}(\mathrm{II})$ presence (WANG et al., 2008). When using Fe(II), preadjustment of $\mathrm{pH}$ consumes more acid, once it has to achieve an acidic $\mathrm{pH}(\approx 3.0)$. Whereas, for the experiments conducted using ferrioxalate $\left(\left[\mathrm{Fe}\left(\mathrm{C}_{2} \mathrm{O}_{4}\right)_{3}\right]^{3-}\right)$ and Vis light, $\mathrm{pH}$ was reduced only to 5 , once this iron(III) source is reported to achieve efficient color and organic matter reduction on higher $\mathrm{pH}$ (DIAS et al., 2014). This fact was confirmed here once TDC and color were reduced in these conditions as well. For these experiments only the "wash" and "post-bio" wastewaters were tested.



Figure 4: (4A) Percentage removal of TDC and Residual $\mathrm{H}_{2} \mathrm{O}_{2}$ in "wash" wastewater using $\mathrm{Fe}(\mathrm{III})-\mathrm{V}$ is at a $\mathrm{pH}$ of 5. (4B) Kinetic of TDC removal during the VisFenton Process using $20 \mathrm{mg} / \mathrm{L}$ of $\mathrm{Fe}(\mathrm{II}): 100 \mathrm{mg} / \mathrm{L}$ of $\mathrm{H}_{2} \mathrm{O}_{2}$ and ferrioxalate as iron(III) source.

Regarding TDC reduction for the "wash" wastewater best results were also achieved when using $20 \mathrm{mg} / \mathrm{L}$ of $\left[\mathrm{Fe}\left(\mathrm{C}_{2} \mathrm{O}_{4}\right)_{3}\right]^{3-}$, the highest concentration tested, combined with the lowest concentration of $\mathrm{H}_{2} \mathrm{O}_{2}$ tested $(100 \mathrm{mg} / \mathrm{L})$. In this scenario $\approx 82 \%$ TDC reduction was observed with $0,94 \mathrm{mg} / \mathrm{L}$ of residual peroxide (Figure 4). Color reduction in these conditions was of $86 \%$ (Figure 5). When compared to experiments using $\mathrm{Fe}(\mathrm{II})$, it is important to note that reaction kinetics was different and $\mathrm{Fe}$ (III) conditions probably needs longer time for hydroxyl radicals to be formed and degrade pollutants.

Here, the same concentration of oxalate acid $(80 \mathrm{mg} / \mathrm{L})$ was used for all of the experiments, independently on the Fe(III) concentration added. According to Dias (2014), when Fe(III)-oxalate complexes are formed in the Fenton system, they may prevent complexes such as $\mathrm{Fe}(\mathrm{III})$-pollutant from forming, which increases the degrading rate. It is important to highlight that for the best degradation rate obtained 
Fe/Oxalate mass ratio used was 1:4 which is similar to optimum ratios obtained by other authors with diverse wastewaters (DIAS et al., 2014; VERDRENNE et al., 2012).

For the "post-bio" wastewater, major reduction of TDC was also achieved with the same combination as in the iron(II)-UV experiments $\left(100 \mathrm{mg} / \mathrm{L}\left[\mathrm{Fe}\left(\mathrm{C}_{2} \mathrm{O}_{4}\right)_{3}\right]^{3-}: 500\right.$ $\mathrm{mg} / \mathrm{L} \mathrm{H}_{2} \mathrm{O}_{2}$ ). However, reduction here was equal $67 \%$ and residual peroxide was a little higher, $12 \mathrm{mg} / \mathrm{L}$. For this same combination, color reduction was of $76 \%$ and visually noticed as for the former experiments (Figure 5).

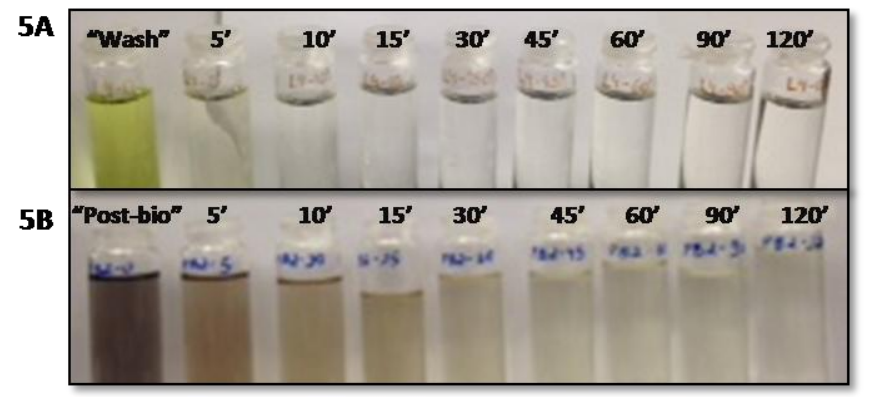

Figure 5- Color reduction of "wash'(5A) and "post-bio"(5B) wastewaters using Ferrioxalate-Vis light at a $\mathrm{pH}$ of 5.

When aiming water reuse in the textile industry, it is important to reduce mainly TDC and color in order to avoid product damage. These conditions were appropriately fulfilled by experimental conditions tested here. However, since experiments reported in this work were done in a laboratory scale reactor, a test in a pilot plant must be performed in order to better evaluate industrial conditions. Also, an economical evaluation of the cost-benefit balance involved must be carried out.

\section{CONCLUSIONS}

The photo-Fenton reaction (UV and UV-vis) seems to be efficient for the treatment of textile wastewater when aiming reuse in the industrial process. This could lead to water preservation and economic benefits for the industry itself. More experiments should be performed in order to optimize the process and also to evaluate what the best option may be for the industry: using $\mathrm{Fe}(\mathrm{II})$ with an acidic $\mathrm{pH}$ or working with $\mathrm{Fe}(\mathrm{III})$ which requires a higher Iron input, but permits degradation at a neutral $\mathrm{pH}$. Also, a pilot-plant is needed to prove off method feasibility.

\section{ACKNOWLEDGEMENT}

The authors thank the Foundation for Research Support of the State of Minas Gerais - FAPEMIG, CNPQ and IARA Project - BNDES for the financial support.

\section{REFERENCES}

AHMAD, A. A.; HAMEED, B. H. Effect of preparation conditions of activated carbon from bamboo waste for real textile wastewater. Journal of Hazardous Materials (2010) 173:487-493. 
AMORIM, C. C.; LEAO, M. M. D.; MOREIRA, R. F. P. M. Comparação entre diferentes processos oxidativos avançados para degradação de corante azo Eng Sanit Ambient (2009) v.14 n.4 (out/dez 2009) 543-550.

CARNEIRO, A. P.; NOGUEIRA, R. F. P.; ZANONI, M. V. B. Homogeneous Photo Degradation of C-1 Reactive Blue 4 using a Photo-Fenton Process under artificial and solar radiation. Dyes and Pigments (2006) 74 (2007)

CHUAH, T. G.; JUMASIAH, A.; AZNI, I.; KATAYON, S.; CHOONG, S. Y. T. Rice husk as a potentially low-cost biosorbent for heavy metal and dye removal: an overview Desalination (2005) 175 (2005) 305-316

DIAS, I. N.; SOUZA, B. S.; PEREIRA, J. O. H. O. S.; MOREIRA, F. C.; DEZOTTI, M. R.; BOAVENTURA, R. A. R.; VILAR, V. J. P. Enhancement of the photoFenton reaction at near neutral $\mathrm{pH}$ through the use of ferrioxalate complexes: A case study on trimethoprim and sulfamethoxazole antibiotics removal from aqueous solutions. Chemical Engineering Journal, v. 247, n. 0, p. 302-313, 2014.

DWAF. South African water quality guidelines. (1996).

GERNJAK, W., et al. Photo-Fenton treatment of water containing natural phenolic pollutants. Chemosphere (2002) 50 (2003) 71-78.

GOGATE, P. R.; PANDIT, A. B. A review of imperative technologies for wastewater treatment I: oxidation technologies at ambient conditions. Advances in Environmental Research (2004) 8 (2004) 501-551.

GOMATHI DEVI, L.; GIRISH KUMAR, S.; MOHAN REDDY, K.; MUNIKRISHNAPPA, C. Photo degradation of Methyl Orange an azo dye by Advanced Fenton Process using zero valent metallic iron: Influence of various reaction parameters and its degradation mechanism. Journal of Hazardous Materials, v. 164, n. 23, p. 459-467, 2009.

MEIHONG, L.; LU, Z.; CHEN, Z.; YU, S.; GAO, C. Comparision of reverse osmosis and nanofiltration membrane in the tratement of biological treated textile effluent for water reuse. Desalination (2011) 281 (2011):372-378.

MONTEAGUDO, J. M.; DURAN, A.; CORRAL, J. M.; CARNICER, A. J. M.; FRADES, M. A. A. Ferrioxalate-induced solar photo-Fenton system for the treatment of winery wastewaters. Chemical Engineering Journal (2011) 181-182 (2012) 281-288.

RESENDE, L. P. Reúso na indústria têxtil e lavanderias. Hydro (2012) Abril 2012:1419.

USEPA. Guidelines for Water Reuse. (2004) Washington.

VEDRENNE, M.; VASQUEZ-MEDRANO, R.; PRATO-GARCIA, D.; FRONTANAURIBE, B. A.; HERNANDEZ-ESPARZA, M. de ANDRÉS J. M. A ferrous oxalate mediated photo-Fenton system: Toward an increased biodegradability of indigo dyed wastewaters. Journal of Hazardous Materials (2012) 243:292-301.

VILAR, V. J. P.; PINHO, L. X.; PINTOR, A. M. A.; BOAVENTURA, R. A. R. Treatment of textile wastewaters by solar-driven advanced oxidation processes. Solar Energy, v. 85, n. 9, p. 1927-1934, 2011.

WANG, X.; ZENG, G.; ZHU, J. Treatment of jean-wash wastewater by combined coagulation, hydrolysis/acidification and Fenton oxidation. Journal of Hazardous Materials (2008) v. 153, n. 1-2: p. 810-816,.

WILL, I. B. S.; MORAES, J. E. F.; TEIXEIRA, A. C. S. C.; GUARDANI, R.; NASCIMENTO, C. A. O. Photo-Fenton degradation of wastewater containing organic compounds in solar reactors. Separation and Purification Technology (2004) 34 (2004):51-57. 